\title{
Study to determine the effect of oral Pregabalin premedication on haemodynamic response to laryngoscopy, intubation and carbon dioxide insufflation during laparoscopic cholecystectomy
}

\author{
Harikrishna Allu', Malavika Kulkarni2 ${ }^{*}$, Ekambaram Dinesh ${ }^{3}$ \\ Post Graduate ${ }^{1}$, Associate Professor ${ }^{2 *}$, Assistant Professor ${ }^{3}$ Department of Anaesthesia, Kasturba \\ Medical College, Manipal Academy of Higher Education, Manipal, Karnataka, India.
}

\begin{abstract}
Background:
The process of laryngoscopy and endotracheal intubation is usually associated with exaggerated haemodynamic response. In extreme cases this response may result in myocardial ischaemia, cardiac failure, increase in intracranial pressure and intracranial haemorrhage. Hence our prospective randomized double blinded placebo control study was designed to observe the effect of pregabalin in attenuating this haemodynamic response.
\end{abstract}

\section{Method:}

In this study, 100 adult patients of ASAPS I and II undergoing elective laparoscopic cholecystectomy were included. The patients were randomly allocated into two groups, group $\mathrm{P}$ received $150 \mathrm{mg}$ oral pregabalin and group $\mathrm{C}$ received similarly looking $\mathrm{B}$ complex capsules one hour before the surgery. Heart rate (HR), systolic blood pressure (SBP), diastolic blood pressure (DBP) and mean arterial pressure (MAP) were observed. Sedation score was assessed using Ramsay sedation scale.

\section{Results:}

We observed an increase in all the haemodynamic parameters in both the groups. The percentage change in HR and MAP from baseline at one-minute following intubation was $+33 \%$ and $+28.5 \%$ in control group compared to $+14 \%$ and $+3 \%$ in pregabalin group. Similarly, the percentage change at five minutes after carboperitoneum was $+24 \%$ and $+26 \%$ in control group compared to $+4 \%$ and $+0.8 \%$ in pregabalin group. This difference was statistically significant with $\mathrm{P}$ value $<0.05$. We also found all the patients in acceptable sedation state (score 3 and 4 based on Ramsay sedation scale) in pregabalin group whereas only $40 \%$ patients had a score of 3 in placebo group at 15 minutes following extubation.

\section{Conclusion:}

Oral pregabalin in a dose of $150 \mathrm{mg}$ one hour before the surgery is a safe and effective premedicant in attenuating pressor response to laryngoscopy, intubation and laparoscopy. It also produces good sedation without any adverse effects.

Keywords: pregabalin; laryngoscopy; intubation; carboperitoneum; laparascopic cholecystectomy
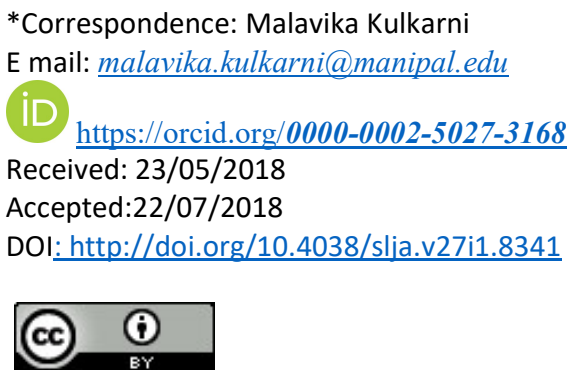

\section{Introduction}

In patients undergoing surgery under general anaesthesia, endotracheal intubation is the gold standard for securing the airway. However, the procedure may cause activation of the sympathetic nervous system and release of catecholamines, resulting in a haemodynamic response that precipitates an increase in Heart Rate (HR) and Mean Arterial Pressure (MAP). This response does not cause problems in most patients; however, in high-risk patient groups, such as those with 
preexisting cardiovascular disease, it may increase the risk of myocardial ischaemia, myocardial infarction and mortality. ${ }^{1-3}$

Significant variations in haemodynamics will occur if carboperitoneum is created with an intraabdominal pressure (IAP) higher than $10 \mathrm{mmHg}$ which is characterized by decrease in cardiac output, increase in arterial pressures and increase in systemic and pulmonary vascular resistances. Sudden stretching of peritoneum may also result in reflex increase of vagal tone leading to bradycardia, cardiac arrhythmia and asystole. ${ }^{4}$ In the head up position given for laparoscopic cholecystectomy there will be a reduction in venous return which results in decrease in cardiac output and MAP and it further complicates the haemodynamic changes by carboperitoneum.

Haemodynamic changes to laryngoscopy, endotracheal intubation and carboperitoneum can be deleterious to patients with compromised cardiac function..$^{5-6}$ Hence, these haemodynamic changes should be attenuated especially in high risk patients. Attenuation of circulatory response to these stimuli is usually done by several methods and medications. However, the armamentarium used for this purpose is ever expanding and all of them have certain limitations and side effects and the lookout for an ideal drug with minimum adverse effects and maximum benefit is of utmost importance.

Pregabalin is a structural derivative of inhibitory neurotransmitter $\gamma$-aminobutyric acid (GABA). The mechanism of action is binding to $\alpha 2 \delta$ subunit of voltage gated calcium channels, reducing calcium influx there by reducing neuronal excitability in central nervous system. There will be reduction in release of neurotransmitters like glutamate, noradrenaline, serotonin, dopamine, substance-p. ${ }^{7}$

Pregabalin is absorbed rapidly, with peak plasma concentration occurring within one hour of administration and mean half-life of 6.3 hours. Dose response relationship calculated allow pregabalin $150 \mathrm{mg}$ /day dose with no need for titration. This drug finds its application as anticonvulsant, analgesic, anxiolytic, treatment of neuropathic pain, partial seizures and fibromyalgia. The adverse effects of pregabalin are transient with somnolence and dizziness being most common. ${ }^{8}$
Hence the current double blind randomized controlled study was carried out to study the effect of pregabalin in attenuating the haemodynamic pressor response to laryngoscopy, intubation and carboperitoneum and to study the sedation score in the two groups.

\section{Methodology}

The present study was started after obtaining approval from the institutional ethics committee. Patients between 18 to 65 years, ASA PS I and II, belonging to either gender, undergoing elective laparoscopic cholecystectomy requiring general anaesthesia and endotracheal intubation were included in the study. Patients with known or suspected allergy to pregabalin, cognitive impairment, history of dizziness, currently using sedatives or anti convulsants, preoperative anticipated difficult air way, laryngoscopy duration of $>20$ seconds or more than one attempt were excluded.

Sample Size: In order to estimate the clinically meaningful reduction of HR and MAP by $10-20 \%$ from the baseline in the intervention group compared to the control group with a level of significance as $5 \%$ for $80 \%$ power of study we needed to study 45 patients in each group. In addition to this, considering $10 \%$ drop out rate we decided to recruit 50 eligible patients in each group.

Patients were evaluated preoperatively, and methodology was discussed with those who satisfied the inclusion criteria. Written informed consent was obtained from those patients. All patients were advised standard nil per oral (NPO) orders, premedicated with tablet pantoprazole $40 \mathrm{mg}$ and metoclopramide $10 \mathrm{mg}$ on the day of surgery. Patients were randomly assigned into two groups using computer generated random sequence allocation. Concealment was ensured using sequentially numbered opaque sealed envelope. An anaesthesiologist who was not a part of data collection premedicated the patient with oral pregabalin $150 \mathrm{mg}$ or similarly looking B-complex 60 minutes before the scheduled surgery with onetwo sips of water. Patient's vital signs and sedation score was monitored in the pre-operative holding area. 
Patient was shifted to operation theatre after confirming adequate NPO status. Multipara monitor consisting of pulse oximetry, non-invasive blood pressure (NIBP), 5 lead ECG were attached, and baseline readings were noted. IV fluids Ringer's lactate (RL)/normal saline (NS) was started at $2 \mathrm{ml} / \mathrm{kg} / \mathrm{hr}$. Preoxygenation with $100 \%$ oxygen, premedicated with i.v. fentanyl $2 \mu \mathrm{g} / \mathrm{kg}$. Induction of anaesthesia using i.v. propofol 2$3 \mathrm{mg} / \mathrm{kg}$. Neuromuscular blockade with i.v. vecuronium $0.1 \mathrm{mg} / \mathrm{kg}$, and plane of anaesthesia deepened with isoflurane1.5-2\%. Oro tracheal intubation was performed after 3 minutes by an experienced anaesthesiologist with minimum duration of laryngoscopy. Maintenance of anaesthesia was done with isoflurane 1-1.2 MAC, $66 \% \mathrm{~N}_{2} \mathrm{O}$, and $33 \% \mathrm{O}_{2}$. Oro gastric tube was inserted five minutes after intubation. The patients were mechanically ventilated to maintain normocapnia. Intraoperatively i.v. paracetamol $15 \mathrm{mg} / \mathrm{kg}$ was given to all patients. The abdomen was inflated with $\mathrm{CO}_{2}$ and IAP was maintained at or below $15 \mathrm{~mm} \mathrm{Hg}$ throughout the procedure. Patient was positioned in anti-trendelenburg position and rotated towards left side to facilitate the exposure of gall bladder.

Patients were monitored for intraoperative complications such as hypertension, hypotension, bradycardia, tachycardia and hypercapnia and treated accordingly. At the end of surgery oral suction was performed and residual neuromuscular blockade was antagonized with i.v. neostigmine $0.05 \mathrm{mg} / \mathrm{kg}$ and glycopyrrolate $0.01 \mathrm{mg} / \mathrm{kg}$. Extubation was performed once patient began breathing spontaneously, following verbal commands, intact gag reflex, ability to generate tidal volumes of $6 \mathrm{ml} / \mathrm{kg}$ body weight and no fade detected with a DBS stimulus at $40 \mathrm{~mA}$ using PNS

\section{Observations:}

1. Heart rate and non-invasive blood pressure, (systolic, diastolic and mean arterial pressures) noted at the following intervals.

- Base line values before premedicating the patient with study drug

- 60minutes after premedication of the patient

- Prior to the induction of anaesthesia in operating room
- After laryngoscopy and endotracheal intubation

- Every 1 minute for next 5minutes

- Before carboperitoneum

- Immediately after carboperitoneum (P0)

- $5,10,15,30$ minutes after carboperitoneum

- 15 minutes following extubation

Sedation score was calculated at the following timings using Ramsay sedation scale

A. Preoperative before premedication

B. 1 hour after administration of study drug

C. 15minutes after extubation

\section{Data analysis}

The results were analyzed using statistical package for social sciences (SPSS) version 21 in windows 7 in consultation with a statistician. Patient baseline haemodynamic parameters were analyzed using independent sample $t$ test and $\mathrm{p}$ value $<0.00625$ is considered as statistically significant. The inter group and intra group analysis was done using repeated measures of analysis of variance (ANOVA). $\mathrm{P}<0.05$ was considered as statistically significant.

\section{Results}

Table 1: Demographic details of the study subjects

\begin{tabular}{|l|l|l|}
\hline & $\begin{array}{l}\text { Group P } \\
\text { (Pregabalin) }\end{array}$ & $\begin{array}{l}\text { Group C } \\
\text { (Placebo) }\end{array}$ \\
\hline & $\mathrm{n}=50$ & $\mathrm{n}=50$ \\
\hline Age $($ Mean \pm SD) & $42.50 \pm 10.92$ & $44.92 \pm 11.25$ \\
\hline Sex M/F & $21 / 29$ & $23 / 27$ \\
\hline
\end{tabular}

There was no statistically significant difference between the age and gender distribution between the two groups.

Table 2: Comparison of base line haemodynamic parameters between two groups

\begin{tabular}{|l|l|l|l|}
\hline & $\begin{array}{l}\text { Group P } \\
(\text { Mean } \pm \text { SD })\end{array}$ & $\begin{array}{l}\text { Group C } \\
(\text { Mean } \pm \text { SD })\end{array}$ & $\begin{array}{l}\text { value } \\
\text { val }\end{array}$ \\
\hline $\begin{array}{l}\text { HR } \\
\text { beats/min) }\end{array}$ & $78.50 \pm 9.579$ & $71.42 \pm 9.121$ & 0.008 \\
\hline $\begin{array}{l}\text { SBP (mm } \\
\text { Hg) }\end{array}$ & $\begin{array}{l}124.00 \pm 14.76 \\
9\end{array}$ & $\begin{array}{l}116.02 \pm 15.07 \\
2\end{array}$ & 0.009 \\
\hline
\end{tabular}


Kulkarni et al. Sri Lankan Journal of Anaesthesiology: 27(1):8-14(2019)

\begin{tabular}{|lc|c|c|c|}
\hline $\begin{array}{l}\text { DBP } \\
\text { Hg }\end{array}$ & $(\mathrm{mm}$ & $74.52 \pm 13.488$ & $67.86 \pm 11.922$ & 0.010 \\
\hline $\begin{array}{l}\text { MAP } \\
\text { Hg }\end{array}$ & $(\mathrm{mm}$ & $93.76 \pm 12.556$ & $86.08 \pm 12.001$ & 0.007 \\
\hline
\end{tabular}

$\mathrm{p}$ value was calculated using independent sample $\mathrm{t}$ test. All the parameters were statistically comparable between two groups

Figure 1: Comparison of Mean HR at 5 time points between two groups

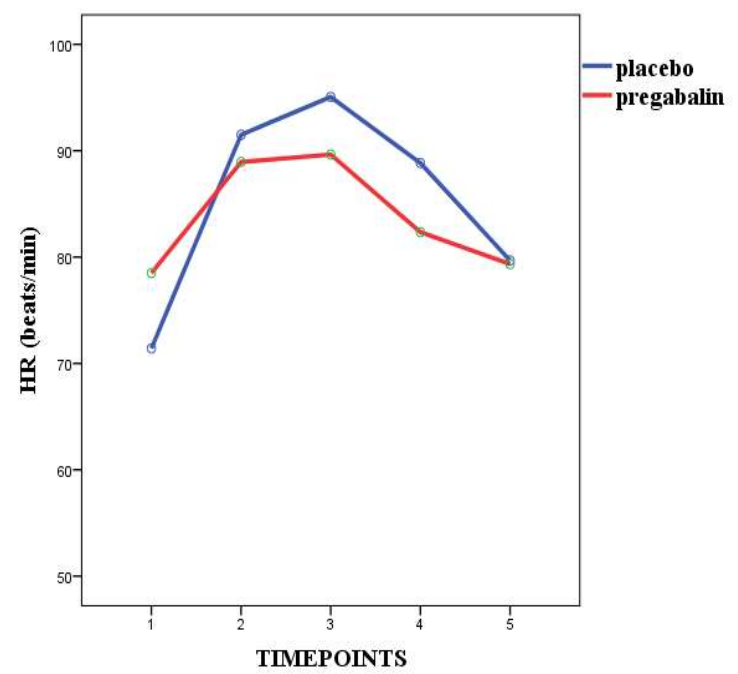

T1- Baseline value before premedication, T 2 following laryngoscopy and intubation, $\mathrm{T} 3$ - 1minute following intubation, $\mathrm{T} 4$ - 5 minutes after carboperitoneum, $\mathrm{T} 5-30$ minutes after carboperitoneum

Table 3: Percentage change of all parameters from baseline (Mean \pm SD)

\begin{tabular}{|c|c|c|c|c|c|c|}
\hline $\begin{array}{l}\text { Variabl } \\
\mathrm{e}\end{array}$ & $\begin{array}{l}\text { Grou } \\
\text { p }\end{array}$ & $\mathrm{T} 1$ & $\mathrm{~T} 2$ & T3 & T4 & T5 \\
\hline $\begin{array}{l}\mathrm{HR} \\
\text { (beats/ } \\
\text { min) }\end{array}$ & $\begin{array}{l}\text { Preg } \\
\text { abali } \\
\mathrm{n}\end{array}$ & $\begin{array}{l}78.50 \\
\pm 9.57 \\
\\
71.42 \\
\pm 9.12\end{array}$ & $\begin{array}{l}88.94 \pm 11 . \\
22 \\
(+13.29 \%) \\
91.50 \pm 10 . \\
42 \\
(+28.11 \%)\end{array}$ & $\begin{array}{l}89.64 \pm 13 . \\
09 \\
(+14.19 \%) \\
95.06 \pm 13 . \\
43 \\
(+33.09 \%)\end{array}$ & $\begin{array}{l}82.34 \pm 13 \\
64 \\
(+4.89 \%) \\
88.84 \pm 12 \\
57 \\
(+24.39 \%)\end{array}$ & $\begin{array}{l}79.34 \pm 11 . \\
345 \\
(+1.07 \%) \\
79.68 \pm 9.3 \\
93 \\
(+11.56 \%)\end{array}$ \\
\hline $\begin{array}{l}\text { SBP } \\
(\mathrm{mmH} \\
\mathrm{g})\end{array}$ & $\begin{array}{l}\begin{array}{l}\text { Preg } \\
\text { abali } \\
\mathrm{n}\end{array} \\
\text { Place } \\
\text { bo }\end{array}$ & $\begin{array}{l}124.0 \\
0 \pm 14 . \\
76 \\
\\
116.0 \\
2 \pm 15 . \\
07\end{array}$ & $\begin{array}{l}130.68 \pm 18 \\
.83 \\
(+5.38 \%) \\
140.96 \pm 17 \\
.40 \\
(+21.49 \%)\end{array}$ & $\begin{array}{l}126.32 \pm 20 \\
.25 \\
(+1.87 \%) \\
137.56 \pm 24 \\
.84 \\
(+18.56 \%)\end{array}$ & $\begin{array}{l}123.22 \pm 18 \\
.16 \\
(-0.62 \%) \\
137.00 \pm 20 \\
.93 \\
(+18.08 \%)\end{array}$ & $\begin{array}{l}118.66 \pm 15 \\
.33 \\
(-4.3 \%) \\
121.54 \pm 16 \\
.92 \\
(+4.75 \%)\end{array}$ \\
\hline $\begin{array}{l}\text { DBP } \\
(\mathrm{mmH} \\
\mathrm{g})\end{array}$ & $\begin{array}{l}\text { Preg } \\
\text { abali } \\
\text { n } \\
\text { Place } \\
\text { bo }\end{array}$ & $\begin{array}{l}74.52 \\
\pm 13.4 \\
8 \\
\\
67.86 \\
\pm 11.9 \\
2 \\
\end{array}$ & $\begin{array}{l}82.94 \pm 13 . \\
27 \\
(+11.29 \%) \\
89.36 \pm 11 . \\
57 \\
(+31.68 \%)\end{array}$ & $\begin{array}{l}77.46 \pm 18 . \\
17 \\
(+3.9 \%) \\
92.66 \pm 13 . \\
31 \\
(+36.54 \%)\end{array}$ & $\begin{array}{l}75.20 \pm 16 . \\
35 \\
(+0.91 \%) \\
89.16 \pm 14 . \\
90 \\
(+31.64 \%)\end{array}$ & $\begin{array}{l}72.86 \pm 10 . \\
63 \\
(-2.22 \%) \\
82.38 \pm 11 . \\
95 \\
(+21.39 \%)\end{array}$ \\
\hline $\begin{array}{l}\text { MAP } \\
(\mathrm{mmH} \\
\mathrm{g})\end{array}$ & $\begin{array}{l}\text { Preg } \\
\text { abali } \\
\text { n }\end{array}$ & $\begin{array}{l}93.76 \\
\pm 12.5 \\
5\end{array}$ & $\begin{array}{l}101.50 \pm 14 \\
.87 \\
(+8.25 \%)\end{array}$ & $\begin{array}{l}96.74 \pm 15 \\
06 \\
(+3.17 \%)\end{array}$ & $\begin{array}{l}94.60 \pm 14 . \\
77 \\
(+0.89 \%)\end{array}$ & $\begin{array}{l}91.30 \pm 12 . \\
72 \\
(-2.62 \%)\end{array}$ \\
\hline
\end{tabular}

\begin{tabular}{|l|l|l|l|l|l|l|}
\hline & & & $109.92 \pm 11$ & $110.66 \pm 13$ & $108.62 \pm 14$ & $97.70 \pm 12$. \\
& Place & 86.08 & .24 & .53 & .24 & 45 \\
& bo & $\begin{array}{l}.2 .0 \\
(+27.6 \%)\end{array}$ & $(+28.55 \%)$ & $(+26.12 \%)$ & $(+13.49 \%)$ \\
\hline
\end{tabular}

T1- Baseline value before premedication, T2following laryngoscopy and intubation, T3- 1minute following intubation, T4- 5 minutes after carboperitoneum, T5- 30 minutes after carboperitoneum

The statistical analysis was done only for four-time points with maximum haemodynamic variations as compared with base line.

There was an increase in all the haemodynamic parameters immediately following laryngoscopy and intubation and in the next minute in both the groups. The maximum percentage change in HR in pregabalin group was $+14 \%$ at 1 -minute following intubation which was clinically not significant $(<20 \%)$ compared to $+33 \%$ in placebo group at same timepoint which was clinically significant. Similarly, the maximum percentage change in MAP in pregabalin group was $+8 \%$ at immediately following intubation which was clinically not significant $(<20 \%)$ compared to $+28 \%$ in placebo group at 1-minute following intubation which was clinically significant. Again at 5 minutes following carboperitoneum the percentage change in HR and MAP was $+4 \%$ and $+0.8 \%$ in pregabalin group which were clinically not significant where as it was $+24 \%$ and $+26 \%$ in placebo group. The inter group analysis by repeated measures of ANOVA showed $\mathrm{p}$ value $<0.05$ which was statistically significant.

Figure 2: Comparison of Mean MAP at 5-time points between two groups

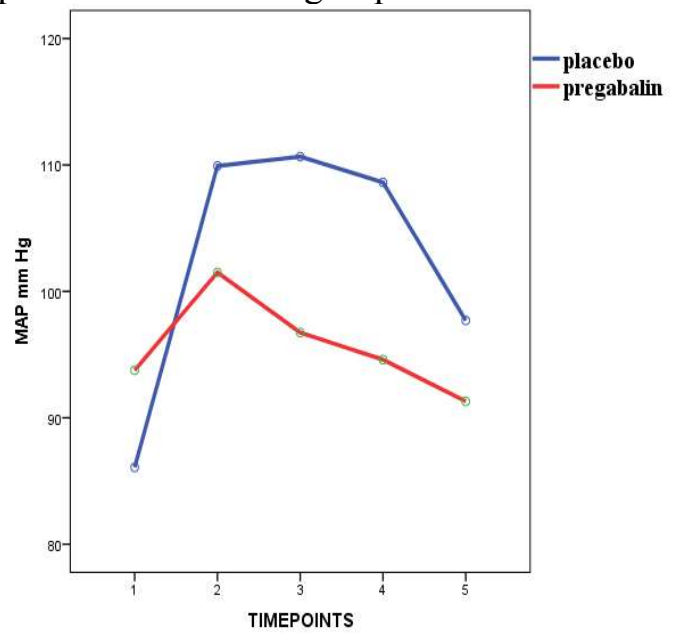


Kulkarni et al. Sri Lankan Journal of Anaesthesiology: 27(1):8-14(2019)

T1- Baseline value before premedication, T2following laryngoscopy and intubation, T3- 1minute following intubation, T4- 5minutes after carboperitoneum, T5- 30minutes after carboperitoneum

Table 4: Distribution of study subjects based on sedation scores as per ramsay sedation scale at different time points

\begin{tabular}{|c|c|c|c|c|c|c|}
\hline & \multicolumn{3}{|c|}{ Placebo Group $(\mathrm{N}=50)$} & \multicolumn{3}{|c|}{ Pregabalin groun $(\mathrm{N}=50)$} \\
\hline $\begin{array}{l}\text { Sedati } \\
\text { on } \\
\text { Score }\end{array}$ & $\begin{array}{l}\text { Befor } \\
\mathrm{e} \\
\text { medic } \\
\text { ation }\end{array}$ & $\begin{array}{l}\mathrm{hr} \\
\text { post } \\
\text { medic } \\
\text { ation }\end{array}$ & $\begin{array}{l}15 \mathrm{~min} \\
\text { after } \\
\text { extuba } \\
\text { tion }\end{array}$ & $\begin{array}{l}\text { Before } \\
\text { medica } \\
\text { tion }\end{array}$ & $\begin{array}{l}\text { 1hr } \\
\text { post } \\
\text { medica } \\
\text { tion }\end{array}$ & $\begin{array}{l}15 \\
\text { min } \\
\text { after } \\
\text { extu } \\
\text { batio } \\
n\end{array}$ \\
\hline 2 & 50 & 50 & 30 & 50 & 10 & - \\
\hline 3 & - & - & 20 & - & 40 & 15 \\
\hline 4 & - & - & - & - & - & 35 \\
\hline
\end{tabular}

The score of three or four was considered adequate sedation. None of the patients had a score of 1,5 or 6. All the patients in pregabalin group had score 3 or 4 at 15 minutes following extubation, whereas only 20 patients in placebo group had a score of 3 . None of the patients in both the groups have excessive sedation score of 5 or 6 . The data was analyzed using Fisher's exact test and $\mathrm{p}$ value was $<0.05$ which was statistically significant.

\section{Discussion}

In the present study all the haemodynamic parameters following laryngoscopy, intubation and carboperitoneum were well within permissible limits in the patients in pregabalin group compared to placebo group.

Mikawa $\mathrm{K} \mathrm{et}^{9}{ }^{9}$ found attenuation of hypertension but not tachycardia with intravenous diltiazem administered $1 \mathrm{~min}$ prior to laryngoscopy. Wilson I et $\mathrm{al}^{10}$ had given $1.5 \mathrm{mg} / \mathrm{kg}$ of i.v. lignocaine to three groups of patients at $2 \mathrm{~min}, 3 \mathrm{~min}, 4 \mathrm{~min}$ before intubation and observed no effect on HR but significant decrease in MAP compared to placebo. Fassoulaki A et $\mathrm{al}^{11}$ found gabapentin premedication attenuated pressor response to laryngoscopy and intubation with no effect on HR. Jee $\mathrm{D}$ et $\mathrm{al}^{12}$ reported the attenuation of increased arterial pressure following laparoscopic cholecystectomy by i.v. magnesium sulphate.

Menigaux $\mathrm{C}$ et $\mathrm{a}^{13}$ observed esmolol attenuating pressor response to laryngoscopy. In the study the authors found that esmolol was more effective in attenuating tachycardia than arterial pressures.

Pregabalin is also a gabapentenoid compound with similar mechanism of action as gabapentin with added advantages such as higher potency, stronger binding affinity to receptor and absorption hence a linear pharmacokinetic profile, $90 \%$ bioavailability, in a dose of $150-600 \mathrm{mg} /$ day. ${ }^{8}$ On the basis of these advantages of pregabalin over gabapentin we decided to study the effect of pregabalin on haemodynamic responses.

In order to ensure uniformity with regard to nature of surgery and its duration, position of patient, it was decided to observe the effect of pregabalin on haemodynamic response following carboperitoneum. The half-life of pregabalin is 6 hours, hence effects of pregabalin would very well persist beyond the average duration of laparoscopic cholecystectomy around 90-120 minutes.

In our study we found an attenuation of HR, SBP, DBP, and MAP in pregabalin group patients compared to placebo group. The maximum percentage increase in HR in placebo group was $33 \%$ where as it was only $14 \%$ in pregabalin group and the maximum percentage increase in MAP in placebo group was $28 \%$ were as it was only $8 \%$ in pregabalin group showing a clinically significant difference between the two groups. We also observed at 5minutes following carboperitoneum clinically significant increase in haemodynamic parameters in placebo group $(\mathrm{HR}+24 \%$, $\mathrm{MAP}+26 \%$ ) compared to pregabalin group $(\mathrm{HR}+4 \%$, MAP $+0.8 \%)$. The results in our study have shown that patients receiving pregabalin are having attenuation response to haemodynamic parameters during laryngoscopy, intubation and laparoscopy.

The reason for this attenuation response of pregabalin and even gabapentin is not known. Gabapentinoids acts by decreasing the excitatory neurotransmitters including noradrenaline and this might be responsible for attenuation of haemodynamics. ${ }^{7,8}$

Ali et $\mathrm{al}^{14}$ demonstrated that preoperative premedication with oral gabapentin attenuated the pressor response to tracheal intubation in adults 
with no effect on basal plasma catecholamine concentration, on the contrary there was an increase in noradrenaline levels. There is a need for further studies to measure catecholamine levels and compare them at respective time points between the intervention and placebo groups to ascertain the attenuation of pressor response by pregabalin.

The sedation levels of the patients were assessed using Ramsay sedation scale pre and post operatively. At 1 hour after premedication 40 patients in pregabalin group had a score of 3 which is acceptable sedation whereas none of the patients in placebo group had a score of 3 . None of the patients in both the groups had excessive sedation.

Meena $\mathrm{R}$ et al ${ }^{15}$ conducted a study on attenuation of cardiovascular response during laryngoscopy and intubation using different doses of oral pregabalin in $150 \mathrm{mg}$ and $300 \mathrm{mg}$ in controlled hypertensive patients. Oral pregabalin in a dose of $300 \mathrm{mg}$ was a better premedicant compared to $150 \mathrm{mg}$ as it not only blunted the arterial pressor response to laryngoscopy and intubation, but also provided anxiolysis with reduction of intra-operative anaesthetic drug requirement and maintained haemodynamic stability without significant adverse effects. Waikar $\mathrm{C}$ et al ${ }^{16}$ compared oral gabapentin, pregabalin, and clonidine as premedication for anxiolysis, sedation, and attenuation of pressor response to endotracheal intubation. They concluded that for attenuation of pressure response for orotracheal intubation, pregabalin was better than gabapentin and clonidine. However, clonidine was better for attenuation of tachycardia response. All the drugs were equally efficacious anxiolytics.

The results in our study are in agreement with the study conducted by Bhawna $\mathrm{R}$ et $\mathrm{al}^{17}$ who found adequate sedation, analgesia, haemodynamic stability in patients premedicated with pregabalin $150 \mathrm{mg}$. Similarly, Sundar et $\mathrm{al}^{18}$ found good attenuation response with pregabalin $150 \mathrm{mg}$ to laryngoscopy and intubation in patients undergoing off pump coronary artery bypass grafting.

None of the patients in our study encountered any adverse effects of pregabalin like dizziness, somnolence, and blurred vision. No patient in our study encountered excessive sedation leading to respiratory depression and desaturation.

\section{Conclusion}

Oral pregabalin in a dose of $150 \mathrm{mg}$, one hour prior to surgery is a safe and effective premedicant in attenuating pressor response among adult patients requiring laryngoscopy, intubation and laparoscopy. It also produces good sedation without prolongation of recovery time and has no adverse effects.

\section{References}

1. Doleman B, Sherwin M, Lund JN, Williams JP. Gabapentin for the hemodynamic response to intubation: systematic review and meta-analysis. Can J Anaesth. 2016 Sep;63(9):1042-58.2

2. Low JM, Harvey JT, Prys-roberts C and Dagnino.J. Studies of anaesthesia in relation to hypertension VII: adrenergic responses to laryngoscopy Br.J. Anaesth.1986;58:471-477 https://doi.org/10.1093/bja/58.5.471

3. Shribman AJ, Smith G, Achola KJ. Cardiovascular and catecholamine response to laryngoscopy with and without tracheal intubation. Br J Anaesth 1987; 59:295-299.

https://doi.org/10.1093/bja/59.3.295

PMid:3828177

4. Jean LJ. Anesthesia for laparoscopic surgery - Millers anesthesia; 7th edition. Elsevier, Philadelphia; 2010: 2185-2197

5. Edwards N D, Alford AM, Dobson P M S, Peacock J E and Reilly C S. Myocardial ischaemia during tracheal intubation and extubation. Br. J. Anaesth. 1994;73(4):537-539

https://doi.org/10.1093/bja/73.4.537

6. Robert GB, Richard W Increased cerebrospinal fluid pressure during laryngoscopy and intubation for induction of anesthesia; AnesthAnalg 1975; 54(5): 687-690

7. Ben-Menachem E. Pregabalin pharmacology and its relevance to clinical practice. Epilepsia 2004;45Suppl 6:13-18 https://doi.org/10.1111/j.0013-9580.2004.455003.x PMid:15315511

8. Gajraj NM. Pregabalin: Its pharmacology and use in pain management. Anaesth and Analg 2007; 105: $1805-1815$

https://doi.org/10.1213/01.ane.0000287643.13410.5e PMid:18042886

9. Mikawa K, Ikegaki J, Maekawa N, Goto R, Kaetsu R and Obara $\mathrm{H}$ The effect of diltiazem on the cardiovascular response to tracheal intubation. Anaesthesia 1990;45(4): 289-293 https://doi.org/10.1111/j.1365-2044.1990.tb14734.x PMid:2337212 
Kulkarni et al. Sri Lankan Journal of Anaesthesiology: 27(1):8-14(2019)

10. Wilson I. G, Meiklejohn B.H and Smith G; Intravenous lignocaine and sympathoadrenal responses to laryngoscopy and intubation The effect of varying time of injection Anaesthesia 1990;46(3): 177-180

https://doi.org/10.1111/j.1365-2044.1991.tb09403.x

11. Fassoulaki A, Melemeni A,Paraskeva A.and. Petropoulos G gabapentin attenuates the pressor response to direct laryngoscopy and tracheal intubation $\mathrm{Br} \mathrm{J}$ Anaesth 2006;96(6):769-73 https://doi.org/10.1093/bja/ael076

PMid:16595614

12. Jee $D$, Lee $D, Y$ un $S$ and Lee C. Magnesium sulphate attenuates arterial pressure increase during laparoscopic cholecystectomy $\mathrm{Br} \quad \mathrm{J}$ Anaesth 2009;103(4): 484-89

https://doi.org/10.1093/bja/aep196

PMid:19617379

13. Menigaux C, Guignard B, Adam F, Sessler DI, Joly $\mathrm{V}$ and Chauvin M. Esmolol prevents movement and attenuates the BIS response to orotracheal intubation Br J of Anaesth 2002;89 (6): 857-62

https://doi.org/10.1093/bja/aef275

PMid: 12453930

14. Ali AR, El Gohary M, H. Salah El-din A, ElKerdawy HM, Essa HH. Efficacy of preoperative oral gabapentin in attenuation of neuro-endocrine response to laryngoscopy and endotracheal intubation. J Med Sci 2009; 9(1); 24-9. https://doi.org/10.3923/jms.2009.24.29

15. Meena R, Meena K, Prakash S. Study of Attenuation of Cardiovascular Response during Laryngoscopy and Intubation Using Two Different Doses of Pregabalin as Premedication in Controlled Hypertensive Patients-A RCT. J AnesthClin Res 2016; 7(2): 607. https://doi.org/10.4172/2155-6148.1000607

16. Waikar C, Singh J, Gupta D, Agrawal A. Comparative Study of Oral Gabapentin, Pregabalin, and Clonidine as Premedication for Anxiolysis, Sedation, and Attenuation of Pressor Response to Endotracheal Intubation. Anesthesia, Essays and Researches. 2017;11(3):558-60.

https://doi.org/10.4103/aer.AER 3417

PMid:28928547 PMCid:PMC5594766

17. Bhawna R, Gupta K, Gupta PK, Agarwal S, Manish $\mathrm{J}$ and Himanshu C. Oral pregabalin premedication for attenuation of haemodynamic pressor response of airway instrumentation during general anaesthesia: A dose response study. Indian $\mathrm{J}$ Anaesth. 2012; 56(1): 49-54.

https://doi.org/10.4103/0019-5049.93344

PMid:22529420 PMCid:PMC3327071
18. Sundar A, Rajesh kumar K, Sulaiman S, Harish R, Karthekeyan R and Mahesh V. The effects of preemptive pregabalin on attenuation of stress response to endotracheal intubation and opioid sparing effect in patients undergoing off-pump coronary artery bypass grafting. Ann Card Anaesth 2012; 15: 18-25.

https://doi.org/10.4103/0971-9784.91473

PMid:22234017 